\begin{tabular}{|c|c|c|c|}
\hline Article Info & RESEARCH ARTICLE & ARAŞTIRMA MAKALESİ & \\
\hline Title of Article & \multicolumn{2}{|c|}{$\begin{array}{c}\text { Why Do We Read Marx in Contemporary } \\
\text { Urban Theory? }\end{array}$} & \\
\hline $\begin{array}{l}\text { Corresponding } \\
\text { Author }\end{array}$ & \multicolumn{2}{|c|}{$\begin{array}{l}\text { Leman İNCEDERE } \\
\text { Manisa Celal Bayar Üniversitesi, Fen-Edebiyat Fakültesi, leman.incedere@@cbu.edu.tr } \\
\text { lemanincedere@hotmail.com }\end{array}$} & \\
\hline $\begin{array}{l}\text { Received Date } \\
\text { Accepted Date }\end{array}$ & \multicolumn{2}{|l|}{$\begin{array}{l}10.05 .2020 \\
16.11 .2020\end{array}$} & \\
\hline Author / Authors & Leman İNCEDERE & ORCID: 0000-0002-0212-6040 & \\
\hline How to Cite & \multicolumn{2}{|c|}{$\begin{array}{l}\text { İncedere, L. (2020). Çağdaş Kentsel Teorilerde Marx’ı Neden Okuyoruz?, Kent } \\
\text { Akademisi, Volume, 13, Issue 4, Pages, 640-650 }\end{array}$} & $\begin{array}{l}\text { Kent Akademisi } \\
\text { Urban Academy }\end{array}$ \\
\hline
\end{tabular}

\title{
Çağdaş Kentsel Teorilerde Marx'ı Neden Okuyoruz?
}

\begin{abstract}
:
In order to make sense of critical urban theories that have an important place in urban studies today, it is undeniable that Karl Marx, whose thoughts were needed to be read again, from the 19th century to the 21 st century, whose need to be read again. The attempt to use the idea of Marx, which echo in a wide range from economy to politics, from sociology to philosophy, to take the meaning of the modern world, is among the dominant intellectual movements of the 21 st century. As a trend that emerged as a reaction to social inequality and injustice, Marxism continues to take place as a parameter in studies based on critical urban theory. The reconciliation points of Marx neo marxist and modern Marxist theorists and the areas in which they differ are very important. In this study, it is aimed to make an analysis on the basic concepts of Karl Marx in order to make sense of the ground studies, in which the contribution of classical Marxist theory to critical urban theory debates based on neo-Marxist approach can be evaluated.
\end{abstract}

KEYWORDS: Marx, Marxism, City, Inequality

ÖZ:

Günümüzde kent çalışmalarında önemli bir yeri olan eleştirel kent teorilerini anlamlandırabilmek için ilk eserlerini vermeye başladığ1 19. yüzyıldan 21. yüzyıla kadar düşünceleri sürekli yeniden okunma ihtiyacı duyulan Karl Marx'ın daha iyi anlaşılmasının gerekliliği yadsınamaz. Ekonomiden siyasete, sosyolojiden felsefeye kadar çok geniş bir alanda yankı bulan Marx'ın fikirlerini çağdaş dünyayı anlamlandırmak için kullanma girişimi, 21. yüzyılın baskın entelektüel akımları içinde yer almaktadır. Toplumsal eşitsizlik ve adaletsizliğe tepki olarak ortaya çıkmış bir akım

${ }^{1}$ Manisa Celal Bayar Üniversitesi, Fen Edebiyat Fakültesi. Coğrafya lemanincedere@hotmail.com 
olan Marksizm özellikle eleştirel kent teorisine dayanan çalışmalarda önemli bir parametre olarak yer almaya devam etmektedir. Marx, modern Marksist ve Neo-Marksist teorisyenlerin fikirlerinin uzlaşı noktaları ve farklılık gösterdikleri alanlar oldukça önemlidir. Bu çalışmada, klasik Marksist geleneğin, Neo-Marksist yaklaşıma dayanan eleştirel kent teorisi tartışmalarına katkısının değerlendirilebileceği zemin çalışmalarını anlamlandırabilmek için Karl Marx'ın temel kavramları üzerinden bir inceleme yapılması amaçlanmıştır.

ANAHTAR KELIMELER: Marx, Marksizm, Kent, Eşitsizlik.

\section{GİRIŞ:}

Ekonomik coğrafya, 19'uncu yüzyılda ekonomik yapının oluşturduğu coğrafyaları açıklamak ve anlamaya çalışmak için genellikle Avrupa güçlerinin ticari yapılarını inceleyen bir coğrafya anlayışına dayanıyordu (Barnes ve Sheppard, 2003). Ekonomik, sosyal, kültürel ve politik anlamda dünya tarihinde en önemli gelişmelerden biri olan sanayi devrimi coğrafi alanda yapılan çalışmalarda köklü bir değişim yaratmıştır. Üretim tarzının değişmesinin en önemli yansımaları kentlerde görülmeye başlamıştır. Kentlerin metalaştırılması ile ilgili ilk çalışma Marksist teorinin kurucularından Friedrich Engels tarafından 1844 yılında yapılmıştır ${ }^{2}$. Kapitalist üretim tarzının İngiliz emekçi sınıfı üstündeki etkileri temalı çalışmasında Engels, kentlerin kapitalizm ile dönüşümünü Manchester özelinden incelerken, kapitalizmin yarattığg sömürünün ve ayrımcılığın sadece iş yerine özgü olmadığını, kent mekânlarında da benzer bir yapının ortaya çıktığını savunmuştur. Bu dönemden itibaren kapitalizmin yarattığı eşitsizlik ve sömürüye bağlı olarak kentsel mekânlarda ayrışmalar giderek artmaya başlamıştır. Karl Marx, 1837'de Hegel eleştirileri ile başladığı erken dönem yazıları, Feuerbach, Komünist Menifesto, Grundrisse ve 3 ciltten oluşan Kapital gibi tarihe damgasını vuran eserleri ile kapitalist üretim ilişkilerinin doğuşunu ve toplumun bununla birlikte dönüşümünü anlamak için sağlam bir kuramsal ve kavramsal çerçeve sağlamıştır (Castells 1977, Wolff 2002, Dumenil ve Levy 2008, Castree 2013) Ancak dönemin şartları ve İngiltere özelinde kalan yazımlar geç kapitalistleşen toplumların ve küreselleşmenin dinamiklerini açıklamakta yetersiz kalmaktadır. Hem bu eksiği tamamlamak hem de Marksizm'den hareketle yeni açılımlar geliştirmek için 20. Yüzyıl boyunca Marksist yazın adı verilen bir yazın türü ortaya çıkmıştır. Toplumsal ve mekânsal diyalektiğin, kentsel olanın teorik özelliğinin ve kapitalizmin varlığını sürdürmesinde eşitsiz gelişmenin hayati bir rolü vardır. $\mathrm{Bu}$ üç tema, temel Marksist kavramları ve analiz yöntemlerini kullanarak eleştirel toplumsal teoride mekânın yeniden ileri sürülmesi adına önemli bir sıçrama tahtası sağlamıştır (Soja, 2017; 14).

Özellikle 1980 sonrası neoliberal politikaların artması ve yaygınlaşması ile gelişmiş ülkeler de dâhil olmak üzere pek çok ülkenin kentlerinde eşitsiz gelişme sorununun büyüyerek devam ettiği görülmektedir. Dolayısıyla kentsel ve bölgesel araştırmalarda eşitsiz gelişme konusu ve dolayısıyla da Marx ve onun düşünceleri ile ilgili çalışmalar 1970'lerin ve 1980'lerin sonlarından günümüze kadar dikkat çekerek artmaya devam etmiştir (Dunford, 1988; Fainstein, 1996, Dean ve Melrose, 1999; Dorling, 2015; Harvey, 2013, 2015; Massey, 1984; Musterd ve Ostendorf 1998; Marcuse, 2002; Smith, 2017; Lefebvre 2016a, 2017; Soja, 2010). Her ne kadar günümüzün modern Marksist yazarları Marx'ın fikirlerine eleştirel bir bakış ile yaklaşarak, pek çok yeni bakış açısı üzerinde dursalar da Marx'1 anlamlandırmak ve onu doğru irdelemenin önemi hiçbir zaman göz ardı edilmemiştir.

\section{Eşitsizlik Kavramı ve Karl Marx}

Eşitsizlik, insanlık tarihi boyunca var olan, üzerinde çok düşünülmüş ve tartışılmış bir kavramdır. Platon'dan ve Aristo'dan başlayarak St. Thomas, St. Augustine'e onlardan da Hobes, Locke, Burke, Bentham, Rousseau ve Hegel'e kadar bütün büyük düşünürlerin eserlerinde bu konunun enine boyuna tartışıldığ1 görülmektedir. Eşitsizlik konusundaki çağdaş araştırmacıların en çok etkilendiği düşünürlerin Karl Marx ve Max Weber olduğu, hatta bu iki düşünürün bazı yönlerden birbirlerini tamamlama özelliği gösterdiği söylenebilir. Gerçekten de Marx toplumsal ekonomik sınıflar arası karşıtlıkları toplumun en önemli özelliği saymış ve toplumsal değişimin başat kaynağı olarak görmüştür. Marx’ın eşitsizliğin ekonomik boyutuna verdiği önem Weber tarafından da kabul edilmiştir. Her iki düşünür de bireyin ya da sınıfın yaşam olanaklarının saptanmasında mülkiyeti temel olgu olarak almıştır (Tan, 1981: 77-78).

\footnotetext{
${ }^{2}$ Bu çalışma günümüzde "İngiltere'de Emekçi Sınıfların Durumu” adıyla dilimize çevrilmiştir (bkz. Engels, F. 2013. İngiltere’de Emekçi Sınıfların Durumu (Çev. Oktay Emre). Ayrıntı Yayınları: İstanbul)
} 
Eşitsizliği tek boyutlu olarak düşünmek onun ortaya çıkmasında ve günümüze kadar artarak devam etmesinde etken olan unsurları bir bütün halinde incelememizi engelleyecektir. Eşitsizlik sorununu düşünürken hem felsefi savlar hem de sosyo-ekonomik bir çözümleme faydalı olacaktır. Eşitlik üzerine önemli çalışmalar yapan, bu çalışmalarıyla da Fransız Devrimi üzerinde etkili olan Jean Jacques Rousseau, özel mülkiyete yönelttiği eleştirilerle Marksist düşünceyi de etkilemiştir. Rousseau'nu insanlar arasındaki eşitsizliğin doğal bir olgu olup olmadığını ve bunun sonuçlarını “Insanlar Arasındaki Eşitsizliğin Kaynă̆g ve Temelleri Üzerine” kitabında sorgulamaktadır.

“...Sadece bir tek kişinin yapabileceği işlere, bir tek elin katılmasına gerek göstermeyen sanat ve hünerlere özenle çalıştıkları sürece doğalarının olanak verdiği kadar, doğaları gereği olabilecekleri kadar özgür, sıhhatli, iyi, mutlu yaşadllar... Fakat ne zaman ki, işin içerisine iş bölümü ve özel mülkiyet girdi, o zaman özgürlük de eşitlik de tarihe karıştı ve bir daha geri dönülmesi mümkün olmayan uygar toplum kurulmuş oldu. "...Bir insanın yardımına gereği olduğundan beri, bir kişinin iki kişiye yetecek kadar yaşama araç ve gereçlerine sahip olmasının yararlı ve kârlı olduğunun fark edildiği andan beri eşitlik kayboldu, mülkiyet işe karıştı..." (Rousseau; 1995: 146).

Rousseau uygarlığın doğuşu ile özel mülkiyetin başladığını ve bunun bir kısır döngü şekilde sürekli eşitsizliği doğurduğunu savunan ilk düşünürlerden bir tanesidir. Rousseau ayrıca yazılarında özel mülkiyetin yarattığı hukuk ve politik düzen üzerine de dikkat çekmiştir.

“..Bir toprak parçasının etrafinı çitlerle çevirip 'Bu, bana aittir' diyebilen ve buna inanacak kadar saf insanlar bulabilen ilk insan, uygar toplumun gerçek kurucusu oldu” (Rousseau, 1995:135). "Mülkiyet bir defa kabul edilince de, bunun sonucu olarak ilk hukuk kurallarl doğmuş oldu” (Rousseau, 1995: 149).

Lefebre'ye göre (2016:18) Rousseau'dan yaklaşık bir asır sonra dünyaya gelen Marx onun düşüncelerinden de etkilenerek, modern toplumu ortaya çıkaran yeni parametreleri yarattığı çelişkiler açısından değerlendirmiştir. Marx, tarihsel bakımdan insanın doğaya karşı mücadelesini modern sanayinin yarattığı proletaryayla yani işçi sınıfıyla formülleştirmiştir. Daha gençlik yapıtlarından itibaren Marx teknikteki ilerlemenin, doğa üzerindeki egemenliğin artmasının, insanın doğa karşısında özgürleşmesinin ve “modern” toplumda, yani kapitalist toplumda genel zenginleşmenin toplumun büyük bir bölümünü etkilediğini tespit etmiştir. Marx toplumun bir kısmının git gide daha fazla yoksullaşırken, bir kısım elit tabakanın da giderek zenginleşeceğini öngörmüş ve tüm yaşamı boyunca bu durumun analizini ve yol alışını izlemeyi sürdürmüştür.

\section{Marx’ın Doğa-Toplum Yaklaşımı ve İkinci Doğa Olarak Kent}

İnsan yaşamının başladığı ilk dönemlerde doğa; barınma, hayvanların avlanması ya da toplayıcılık gibi daha çok bedenin yaşamı devam ettirmek için gerekli faaliyetlerde kullanılmaktaydı. İnsanlık tarihini doğal tarihten ayıran dönüştürücü an insanların kendilerini bilinçli bir üretim sürecini devreye soktukları zaman ortaya çıktı (Marx, 1979). Marx insan yaşamının kökenlerini bilinçli bir sosyal yaşamda arar. İnsanlar ancak bilinçli ve kasıtlı olarak doğal kaynakları ihtiyaç duyulan malzemelere dönüştürdüklerinde, yani ürettiklerinde diğer hayvanlardan ayrılmışlardır. Bu noktada Marx’ın toplum ve doğa arasındaki ilişkiyi karşılıklı bir etkileşime dayalı olarak betimlemesi önemlidir:

“Emek, her şeyden önce, insan ve doğa arasındaki bir süreçtir. Insanın kendi eylemleri aracılı̆̆ıyla, kendisi ve doğa arasındaki metabolizmaya aracılık ve kontrol ettiği bir süreçtir” (Marx, 1979).

Marx doğa kavramını yorumlarken isabetli bir şekilde doğanın kendisine değil doğa ve toplum arasındaki ilişkiye odaklanır. Marx'ın vurguladığı gibi toplumdan ayrı bir doğanın anlamı yoktur. Çünkü insanlık tarihinin başlamasından önceki doğa bugün artık hiçbir yerde mevcut değildir. Doğa ile kurulan ilişki tarihsel bir üründür ve bu nedenle doğa toplumun dişında konumlandırılmaz.

Marx’ın doğa kavramının iç diyalektiğini oluşturan özgül ilişkileri açığa çıkarmak için “birincil doğa” ve ikinci doğa" olmak üzere bir ayrıma gidilmesi faydalı olacaktır. Birincil doğa insanların dışında var olan şeyler dünyası; ikincil doğa ise devlette, hukukta, toplumda ve ekonomide şekillenen haliyle insanların dünyasıdır. Bu kavramlar özdeş 
olmamalarına rağmen, birbirlerini içerirler. Doğa toplum aracılığıyla dolayımlanır, toplum da doğa aracılı̆̆ıyla. Marx bu dolayımı daha doğru bir ifadeyle bir metabolizma ya da metaboloik etkileşim olarak adlandır (Smith, 2017: 49-50).

Lefebvre'nin mekân üzerine yazdığ1 “Mekânın Üretimi” kitabında kenti ikinci doğa ve üretilmiş mekân olarak kavramsallaştırması dikkat çekicidir. Lefebvre'ye göre (2016b: 349) ikinci doğa olan kent doğanın kimi özelliklerini özellikle kullanım değerini- korur.

"Marx için doğa üretici güçler arasında yer alıyordu. Günümüzde doğa üzerinde tahakküm kurma ile doğayı sahiplenme arasındaki, Marx’ın yapmamış olduğu ayrım zorunlu gözükmektedir. Teknik aracılı̆̆lyla tahakküm, sahiplenmemeye, imhaya yöneliktir. Ayrıca doğa günümüzde kaynak ve imkân olarak görülmektedir. Doğa Marx’ın döneminde olduğundan daha açık seçik bir şekilde kullanım değeri olarak algılanmaktadır” (Lefebvre, 2016b: 347).

Gerçekten de Marx, temel çalışması olan “Kapital: Politik ekonominin Eleştirisi” nde ürünlerin meta formunun analizi ile toplumsal ilişkileri açıklamayı amaçlamıştır. Marx, emtiayı üç ayrı bakış açısıyla değerlendirmeye çalışmıştır; kullanım değeri, değişim değeri ve değer. Birincisi yani emtianın kullanım değeri, maddi yönlerden insanların istek ve ihtiyaçlarını karşılayan kendine özgü fiziksel niteliklerden oluşuyordu. Marx kullanım değeri terimiyle ihtiyaçlar doğrultusunda taleplerin oluştuğunu savunur (talebin bireyin içinde var olan bir dürtüden çok, toplumsal olarak üretilmesi). Marx için kullanım değeri klasik ve özellikle de neoklasik iktisattan ayrılarak sosyal ihtiyaçlara dayanır (Peet ve Hartwick, 2015: 170).

İkinci olarak değişim değeri; değeri temsil etmek için seçilen bir mal cinsinden kullanım değerinin ifadesiydi (para). Marx değişim değerinin, kapitalist sürecin iç yasalarından çok daha geniş anlamlara sahip olduğunu savunmuştur. Gerçekten de bu işlevleri analiz eden Marx bir ödeme aracı olarak paranın, sonuç olarak nasıl bir toplumsal ilişki ve süreç olarak da sermaye haline geldiğini göstermiştir. Bu metanın, değiş tokuş formu aracı olarak paranın kullanılmasını gerekli kılıyordur. Marx’ın formülleştirdiği şekliyle;

"Meta dolaşımının dolaysız biçimi M (Meta)-P (Para) -M (Meta) yani metanın paraya dönüşmesi ve paranın yeniden metaya dönüşmesi, satın almak için satmaktır. Ama, bu biçimin yanında spesifik olarak farklı bir ikinci biçim, P-M-P biçimini de buluruz; burada ilk önce para metaya dönüşür, yani satmak için satın alınır. Bunun sebebi ihtiyaç değildir. Bu son değişimi gerçekleştirmenin tek amacı değişimin sonunda başlangıçtan daha fazla paraya sahip olmaktır. Bu şekilde dolaşan para sermaye haline gelmiştir" (Marx, 2017: 152).

Marx’ın tanımladığı şekliyle değişim değeri, para gibi üretilmiş şeyler için kullanmıştır. Kendi içinde değiş tokuş edilebilen şeylerin bir meta değeri kazanması şeklinde gerçekleşir. Geçmişte bir toprak satılıyor ya da kiralanıyordu. Günümüzde üç boyutlu bir cisim -daire, konut, odalar, katlar, teraslar, çeşitli donanımlar (havuz, tenis kortu, park yeri) alınıp satılmaktadır (Lefebvre, 2016b; 341). Dünyadaki en modern şehircilik projelerinde görülen her şey üretilmiştir; su, toprak, ağaç, bitki. Her şey yapay ve sofistikedir; doğa burada yok olmuştur. Sadece birkaç işaret ve sembol kalır. Kent mekânı doğal mekândan kopmuştur, fakat üretici kapasitelerden yola çıkarak yeniden bir mekân yaratılır. Doğa mekân -en azından belirli sosyo-ekonomik koşullarda- ender bulunur bir mal olur (Lefebvre, 2016b, 334). Bu koşullarda klasik siyasal iktisattan kaynaklanmayan ve iktisatçıların tahminlerini bozan “iktisadi” bir süreç gerçekleşir; gayrimenkul, ikincil bir oluşum olmaktan, sanayi ve finans kapitalizminin uzun süre geri kalmış ek bir dalı olmaktan çıkarak, ön plana geçer. Ve bu ülkelere, momentlere, konjonktüre göre eşitsiz bir biçimde gerçekleşir. Eşitsizlik yasası (büyüme ve gelişme) küreselleşir. Gayrimenkul böylece, genel eşitsizliğe (büyüme eşitsizliğine), sektörleşmeye dâhil olur ((Lefebvre, 2016b: 339).

Üçüncü husus olan emek konusuna geçmeden önce, Marx’ın kullanım değeri ve değişim değeri arasındaki ilişkiye dair düşüncelerine göz atmak gerekmektedir. Marx kullanım değeri ile değişim değerini, malda edindikleri biçim yoluyla diyalektik bir ilişkiye sokmaktadır:

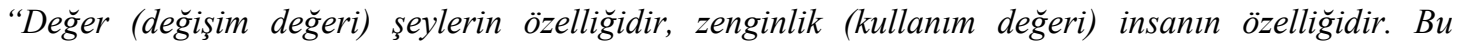
anlamıyla değer, değişimi zorunlu olarak içerir, zenginlik içermez. Zenginlik (kullanım değeri) insanın 
bir özelliği dĕger ise metaların bir özelliğidir. Bir insan ya da topluluk zengindir, bir inci ya da elmas değildir... bir inci ya da elmasın, inci ya da elmas olarak değeri vardır... şeylerin kullanım değeri insan için değişim olmadan, yani insan ile şey arasındaki dolaysız ilişkiyle, buna karşılık değeri ancak değişim değeriyle, yani toplumsal bir süreçle gerçekleşir” (Marx, 2017 91-92).

Basit bir nesne ya da “şey” olarak mal, Marx’ın analizinde yerini basit bir el değiştirme sonucu kökten anlam değişikliğine uğrayabilen, sayısız toplumsal ilişkinin ifadesi olarak mala bırakmaktadır. Marx bu diyalektik ve ilişkisel analiz tarzıyla diğer geleneksel analizlerden farklılaşmıştır. Harvey’e göre (2013: 146) kullanım değeri ile değişim değerini birbiriyle diyalektik ilişkiye sokan Marksist yaklaşım, üzerinde düşünülmeyi hak etmektedir. Çünkü iki olanağı birden sunmaktadır: Hem toprak kullanımının coğrafi ve sosyolojik açıdan araştırılmasına yeni bir soluk getirir, hem de kentsel toprak kullanımı sorunlarıyla mekânsal ve iktisadi yaklaşımlar arasında bir köprü oluşturur. Bu sonuncu husus güncel mekânsal analiz açısından oldukça önemlidir.

Doğanın dolaysız yapısı tarihsel bağlama yerleştirildiğinde, maddi peyzajın gelişmesi kendini doğanın üretilmesi süreci şeklinde ortaya koyar. Doğanın üretilmesi sürecinin farklılaşmış sonuçları eşitsiz gelişimin maddi semptomlarıdır. Dolayısıyla en soyut düzlemde kullanım değeri ile mübadele değeri; mekân ile toplum doğanın üretilmesinde kaynaşır (Smith, 2017: 67).

Marx'ın üzerinde durduğu üçüncü unsur insan emeğidir. Hem Marx hem de klasik ekonomistler, niteliksel olarak farklı kullanım değerlerinin değişimine yol açan unsurun insan emeği olduğu konusunda hemfikir olmuşlardır. Marx için sermaye ve emek arasındaki ilişki tüm tarihsel dönemlerde bu şekilde gerçekleşmemiştir. Bu sömürüye dayalı ve sınıf mücadelesi barındıran ilişki kapitalist sistem ile yoğunlaşmıştır. Erken kapitalizm kapitaliste karşı soylular, işçiler ve köylüler olarak şekillenmiştir. Bunun sonucunda köylülerin bireysel özgürlükleri sınırlandırılmış ve toprak mülkiyetleri ellerinden alınmaya başlamıştır (Peet ve Hartwick, 2015: 170).

Kapitalistler ilk zamanlar ticaret yapan çiftçiler ya da küçük üreticilerden oluşuyordu. Bu üreticiler piyasa koşulları altında ortalama üretim koşullarının düzenlendiği fiyatlarla mal üretmek zorunda kaldılar. Bu baskıyı yaratan başlıca mekanizma "rekabet” olmuştur. Rekabet kapitalist üreticileri işçilerden artı değer çıkarmaya zorladı. Bunun yanı sıra rekabet faktörü kapitalist süreçte üretici güçleri sürekli devrime yöneltmiştir. Yeni teknolojileri ve yenilikçi organizasyon türlerini (örneğin aile şirketleri yerine şirketler, ulusal şirketler yerine çok uluslu şirketler) zorunlu kılmıştır. Marx, bu tarihsel gelişim sürecini bir dizi denge olarak görmekten ziyade eşitsiz ve çelişkili olarak kavramsallaştırmıştır. Marx için kalkınma; sınıf açsından (sahip olan sınıf zenginleştikçe) ve mekânda eşit olmayan bir sermaye birikimi süreciydi. Kalkınma esas olarak, tamamlayıcı sosyal ilişkilerin, sömürü ve rekabetin çelişkili doğasından dolayı, tamamen çelişkili bir süreçtir (Becker, 1977; Harvey, 2002). Marx daha çok sermayenin "ilkel birikimi” olarak adlandırdığı parayla, diğer toplumların zenginlikleri ve kaynakları açısından ilgilenir;

“Amerika'da altın ve gümüşün keşfedilmesi, bu kıtanın yerli nüfusu, Hindistan'ın fethi ve yağmalanması, Afrika’nın siyah tenli halkının köleleştirilmesi, kapitalist üretim çağııın başlangıcını temsil eden her şeydir. Bu gelişmeler ilkel birikimin en önemli olayıdır” (Marx, 1979).

Marx, "ilkel birikim" kavramıyla kapitalist ekonomilerin kalkınmasını sağlamak için servetin tüm dünyadan aktarıldığı süreçleri anlatır. Marksist coğrafyacı David Harvey, “The New Imperialism” kitabında Marx'ın bahsettiği bu ilkel birikim kavramının tüm özelliklerinin, bugüne kadar kapitalizmin tarihi coğrafyasında güçlü bir biçimde kaldığını hatta bazı ilkel birikim mekanizmalarının, geçmişte olduğundan daha güçlü bir rol oynamak için ayarlandığını savunur. Harve'e göre (2003: 145) "Marx'ın ilkel birikim tanımına daha yakından bakıldı̆̆ında çok çeşitli süreçler ortaya çıkıyor. Bunlar, toprakların metalaştırılması ve özelleştirilmesini içerir”.

Kentin metalaştırılması süreci sadece parsel parsel toprak alım satımını veya nüfusun belli kesimlerine özel bölgeler ayrılmasını içermiyor. Burada daha genel olarak, kentsel mekânın sömürülme süreci söz konusudur. İçinde yaşayanlarla, içinde yaşayanların ürettiği toplumsal kaynaklar ve ekonomik eserlerle birlikte mekânın tümü satılmaktadır. Kent hayatının kendisi ekonomik değer biçme sürecine tabii tutulup ve onun üzerinden dönüştürülmektedir (Brenner vd. 2014: 91). 
Doğanın işgücü yoluyla dönüştürülmesine yönelik insan yeteneğinin geliştirilmesi, daha yüksek maddi yaşam standartları ve dolayısıyla daha özgürleşmiş bir varoluş potansiyeli olasılığını artırdı. Bu üretici güçler nasıl ilerledi? Marx çeşitli üretim güçlerini birbirine bağlayan ilişkilerin, bir birlik oluştururken aynı zamanda bir çatışmaya da yol açtığını savunan diyalektik bir anlayışa sahipti. Marx'a göre emeği üretim araçlarıyla birleştiren toplumsal ilişkiler, üretimin gelişiminin niteliğini ve miktarını belirledi. Dolayısıyla sosyal ilişkiler Marx'ın en temel analitik kategorisiydi. Başka bir deyişle tarihsel materyalizmin analitik olarak ayırt edici özelliği Marx’ın sosyal ilişkilere yaptığı vurguda yatmaktadır. Sosyal ilişkiler birçok biçime sahiptir: Aile arasındakiler, arkadaşlar arasındaki ilişkiler, toplum içindeki ilişkiler vb.. İhtiyaçlar ve istekleri karşılayan ürünlerin yapımında doğanın kaynaklarının çıkarılması ve işlenmesi için üretici güçler kullanılarak insan varlığı güvence altına alınır. Marx için en temel sosyal ilişkiler insan varoluşunun üretimi üzerinde kontrol sağlamaya yarar. Sosyal ilişkiler varoluş açısından kontrol olarak iktidar ile ilgilidir. Bu anlayışa göre üretim araçları yönetici bir elit tarafından kontrol altına alındığında, ikinci bir dönüştürücü an ortaya çıktı. Yaklaşık 6 bin yıl önce meydana gelen bu orijinal “arazi kapanı” üretici güçlerin sahipleri ile filli çalışmayı gerçekleştiren işçiler arasında temel bir toplumsal bölünme ya da sınıf bölünmesi yarattı. Ekonomik gelişmede bu olayın hayati yönü, çalışma gününün gerekli emek zamanının ötesine uzatılmasıydı (Peet ve Hartwick, 2015: 169). Marx bu süreci şu şekilde tanımlamıştır:

"Üretim süreci sırasında, sermaye emeğe, yani faaliyet halindeki emek gücüne veya işçinin kendisine kumada edecek hale gelmişti. Kişileşmiş sermaye, yani kapitalist işçinin işini düzenli bir şekilde ve uygun bir yoğunluk derecesinde yapmasına dikkat eder. Bunun ötesinde, sermaye, işçi sınıfının kendi dar ihtiyaçlar toplamının zorunlu kıldığından daha fazla emek harcamasını gerektirecek bir zorlama ilişkisine dönüşmüştü. Başkalarının çalıştıklarının üreticiliği, artık emek yutuculuğu ve emek gücü sömürücülü̈̆̈̈ söz konusu olduğunda, sermaye, enerji, ölçü tanımazlık ve etkililik açısından, doğrudan doğruya angaryaya dayanan geçmişteki bütün üretim sistemlerini çok geride bırakır” (Marx, 2017: 300).

Marx kalkınma terimini günümüzde kullanıldığı şekliyle kullanmamıştır. Sosyal ve ekonomik hayatın dinamikleriyle yoğun bir şekilde ilgilenmesine rağmen ekonominin büyümesini belirlemek için "sermeye birikimi”" terimini kullanmıştır. Sermeye kapitalizm içinde özel mülkiyete ait olduğu için, zaman içinde değişerek toplum üstünde özel bir kontrol anlamına gelir. Büyümenin halkın çabalarıyla gerçekleşmesine rağmen birkaç kişi tarafından kontrol edilmesi sermaye birikiminin (gelişme) çelişkili yapısını ortaya koyuyordu (Peet ve Hartwick, 2015: 164) Doğanın, mekânın ve eşitsiz gelişimin problemleri bizzat sermaye tarafından birbirine bağlanmaktadır (Smith, 2017: 25). Marx yazılarında eşitsizliğin kaynağının “sermaye” olduğunu vurgular. Sermaye sadece ekonomik değil aynı zamanda sosyo-kültürel nitelikte de olabilir. Temelde sermayenin toplum üyeleri arasında eşit bir biçimde paylaşılmaması, sınıfları ve toplumsal eşitsizlikleri yaratmaktadır.

\subsection{Marksizm ve Sinıf Yapısı}

Marx, modern sınıf yapısına dair çalışmasını tamamlayamamış olmasına rağmen yine de temel unsurları ortaya koymayı başarmıştır. Kapitalist toplum formunun sosyolojik ve hukuki yönlerini özetleyen Marx esas olarak ekonomik boyutu ortaya koymuştur. Onun analizi kapitalizme özgü piyasa mekanizmalarının bir araştırmasına dayanmaktadır (Bidet, 2008: 12).

Marx’ın tüm analizleri sınıf mücadelesini içerir. Sermaye, kapitalistler ve proleterler arasındaki çatışma için anahtar kavram olarak kullanılmıştır. Marx'ın ekonomik ve politik yazılarını bir araya getirdiğimizde analitik çerçevenin genişlediğini görüyoruz: Kapitalistler ve toprak sahipleri, sanayiciler ve küçük üreticiler ve maaşlı yöneticiler. Devlet, genellikle tanımlandığı gibi özerk bir ajan olmaktan uzak, doğrudan egemen sınıfların gücünün ve onun tavizlerinin kullanılmasıyla bağlantılıdır. Tarihin otantik okuması, bu güçleri ve mücadeleleri görmezden gelemez. Sistemin dönüşümlerinin her biri, 20. yüzyılın başında modern kapitalizmin kurumlarının ortaya çıkışı, 20. yüzyılın ilk yarısında özel ve kamu yönetimi ve sosyal koruma ya da yeni konunun gelişmesidir. Bunlar neoliberalizme özgü güdülerdir. Politikalar, doğrudan keynesçilikten neoliberalizme doğru olan ifadeleri yansıtmaktadır. 20. yüzyılın başlarındaki kapitalizmdeki değişimlere, işçi sınıfı hareketinin gücü, yönetici sınıfların iç çelişkileriyle birleşerek, merkezi bir rol oynadığı mücadeleler tarafından kumanda edildi. Benzer şekilde, mülk sahiplerinin neoliberalizmdeki gücünün yeniden tespiti, uzun süreli bir çatışmanın, azınlığın ayrıcalıklarını korumak için sürekli bir savaşın bir aşamasının sonucuydu. Bu gibi önemli tarihsel gelişmeler ancak bu çeşitli unsurların birleşimi ile anlaşılabilir hale

Çağdaş Kentsel Teorilerde Marx'ı Neden Okuyoruz?

Journal of Urban Academy | Volume: 13 Issue: 4

ISSN: $2146-9229$

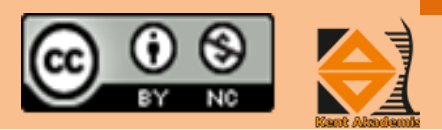


getirilebilir. Marksizm böyle bir yaklaşım için en uygun çerçevedir -ya da öyle olmalıdır- (Dumenil ve Levy, 2008: 117).

Marx için, üretim ve gelişim üzerindeki sınıf kontrolü sosyo-kültürel ve politik yaşam açısından önemli etkiler yaratır. Marx karmaşık sosyal ve ekonomik yapılara, kurumlara, sınıflara ve ekonomik gereklilik ile sembolik bilinç arasında toplumsal ilişkilere bakış açısını "Ekonomi Politiğin Eleştirisine Katkl” kitabında kısaca şöyle formüle etmektedir:

"Maddi hayatın üretim tarzl, genel olarak toplumsal, siyasi ve entelektüel hayat sürecini koşullandırır. Insanların varlığını belirleyen şey, toplumsal varlıklardır. Gelişmelerinin belli bir aşamasında, toplumun maddi üretici güçleri, o zamana kadar içinde hareket ettikleri mevcut üretim ilişkilerine ya da bunların hukuki ifadesinden başka bir şey olmayan, mülkiyet ilişkilerine ters düşer. Üretici güçlerin gelişmesinin biçimleri olan bu ilişkiler, onların engelleri haline gelir. O zaman bir toplumsal devrim çă̆g... İktisadi temeldeki değişme, üstyapıyı, büyük ya da az bir hızla altüst eder. Bu gibi altüst oluşların incelenmesinde, daima, iktisadi üretim koşullarının maddi altüst oluşu ile- ki bu bilimsel bakımdan kesin olarak saptanabilir- hukuki, siyasi, dini, estetik ya da felsefi biçimleri, kısaca, insanların bu çatışma bilincine ve onu sonuna kadar götürdükleri ideolojik şekilleri ayırt etmek gerekir" (Marx, 1979: 24).

Marx bu pasajda ekonomik yapının (güçler ve üretim ilişkileri) genel olarak toplumun üst yapısını (kültür, siyaset, bilinç) belirlediğini, şekillendirdiğini vurgulamaktadır. Marx’ın güçler ve üretim ilişkileri olarak tanımladığı üst yapının ekonomik kısmında, sömürü ve çatışmayla karakterize edilen bir toplumun, elit tahakkümün sağlanması ve üretim koşullarının altyapısının toplumsal olarak yeniden üretilmesi için kolektif kurumlar geliştirilmesi gerektiği görülür.

Marx’ın kültür, siyaset ve bilinç olarak tanımladığı üst yapının politik kısmına dönersek; burjuva sınıfı ve devlet arasındaki ilişkinin nesnel bir ilişki olduğu söylenebilir. Devletin belirleyici bir toplumsal formasyondaki işlevi egemen sınıfın çıkarları ile çakışırsa, sistemin kendisi yüzünden, egemen sınıfın üyelerinin devlet aygıtına doğrudan katılımı söz konusu olduğu için onların çıkarları doğrultusunda karar alınır (Poulantzas, 1969: 73). Marx, kapitalist devletin birçok unsurunun belirli sınıfların çıkarlarını gözetmek üzere kurulduğun ve o yönde hareket ettiğini vurgulamıştır.

\subsection{Marksizm: İdeoloji ve Devlet}

Benzer yönler olmasına rağmen Marx'ın düşünceleri yine de çağdaş modernistlerin çoğundan farklıydı. Marx modern endüstriyel üretimi doğadan daha fazla bağımsız olunabilecek bir özgürleştirici güç olarak gördü, fakat aynı zamanda kapitalist sanayileşmeyi kontrolsüz aşırı kullanım nedeniyle çevreyi yok eden bir doğadan yabancılaşma nedeni olarak tanımladı. Modernliği maddi yaşamda ilerleme olarak gördü ancak bir yandan da kar, sermaye ve birikim tarafından motive edilen, birkaç zengin tarafından yönlendirilen ve eşit olmayan sonuçlara sahip bir hareket olarak yorumladı. Dolayısıyla modern tahayyülde modernist olmakla birlikte Marx'ın teorik analizi toplumu, özelikle de liderlerini değiştirmeyi amaçlayan radikal politiğin bir rehberi olarak tasarlandı (Peet ve Hartwick, 2015: 163).

Marx, tarım ve sanayi üretimindeki iş bölümünün bir ifadesi olarak kent ve ülke ikiliği kavramını ve ulusal ekonominin işleyişinde manüel ve zihinsel çalışmalarda entelektüel bölünmeyi kullanır (Martins, 1982). Marx’a göre devlet kurumlarının karmaşıklığı üretimin çelişkili yapısından kaynaklanır. Dönemler boyunca değişen üretim ilişkileri devlet yapısını da temelden etkilemiştir. Devlet yapısının tam olarak anlaşılabilmesi için belirli bir zaman döneminin, özel koşullarını imcelemek gereklidir. Rosa Luxemburg'un vurguladı̆̆ı gibi;

"Marx’ın değer teorisinin sırrı, para problemini, onun sermaye teorisini, kar oranını ve dolayıslyla tüm ekonomik sistemin teorisini analiz etmesinin sırr, kapitalist ekonominin geçici karakterinde bulunur. ... Çünkü Marx, kapitalizme, tarihsel bakış açısından bakarak kapitalist ekonominin hiyerogliflerini çözmeyi başarmıştır" (Luxemburg, 2013: 58). 
İlk olarak tarihin büyük hareket yasasını keşfeden Marx, tüm tarihsel mücadelelerin ister politik ister dini, ister felsefi ya da başka bir ideolojik alanda ilerlesin az ya da çok sosyal sınıfların mücadelelerinin ifadesi olduğunu belirtir. Bu nedenle, bu sınıflar arasındaki çarpışmalarda ekonomik konumlarının gelişiminin derecesi, üretimlerinin şekli ve onun tarafından belirlenen değişimleri ile koşullu hale getirilir (Marx, 1969: 3).

Marx ve Engels'ın 1948 yılında yayınlanan “Komünist Manifesto” yazıları dört bölümden oluşuyordu. Özellikle proletaryanın devlet aygıtına el koymasıyla ve yoksullaşma ve de sınıf kutuplaşması üzerine yazıları o dönemde oldukça ses getirmiştir. Marx ve Engelse göre;

"Şu ana kadarki tüm toplumların tarihi, sınıf mücadeleleri tarihidir. Özgür insan ile köle, patrisyen ile pleb, lord ile serf, lonca ustası ile kalfa, tek kelime ile ezen ile ezilen sürekli karşı karşıya gelmiştir. Her seferinde ya toplumun tümüyle devrimci bir dönüşüme uğramasıyla ya da çatışan sınıfların ortak yıkımıyla sonuçlanmış, kimi zaman gizli olarak kimi zaman da açıkça, fakat hiç durmadan bir mücadele içinde olmuşlardır. Tarihin önceki dönemlerinde, toplumun neredeyse her yerde çeşitli zümreler halinde tamamen düzenlenişini, toplumsal konumlarını çok yönlü olarak derecelendirişini görüyoruz. Antik Roma'da patrisyenler, şövalyeler, plebler, köleler; orta çağda feodal derebeyleri, vassalar, lonca ustalarl, kalfalar, çıraklar, serfler; ve bu sintfların neredeyse hepsinde de yine özel derecelendirmeler yer almıştır. Feodal toplumun yıkıntısından doğan modern burjuva toplumu, sınıf karşıtlıklarını ortadan kaldıramamıştır. Yalnızca eskilerin yerine yeni sınıflar yeni baskı koşulları yeni mücadele biçimleri geçmiştir." (McLellan, 2017: 271)

Marx'ın ana temalarından biri, Feuerbach'ın Hegel'i materyalist tersyüz edişine canlı bir tarihsel boyut ekleyen "bilinç yaşamı belirlemez, tam tersine yaşam bilinci belirler" temasıydı. Marx’ın bu bakış açısıyla tarihin nesnel bir değerlendirmesi; özel mülkiyete yol açan iş bölümünün, toplumsal iş bölümünün, toplumsal eşitsizliğin yaratılmasının, sınıf mücadelesinin ve politik yapıların inşasının nasıl halka hizmet etmekten çok ona hükmettiğini gösterir (Mc Lellan, 2017: 172). Devlet işlevinin araştırılması, kapitalist birikim sürecinin tarihsel seyrinin kavramsal analizine dayanmalıdır; Bununla birlikte bunun, soyut yasaların mantıksal olarak indirgenmesi değil, tarihsel bir süreç topluluğunun kavramsal olarak ağılanma çabası olduğu unutulmamalıdır. Bu formları geçici olarak kabul etmedikçe, başka akıl yürütme biçimlerine sahip olmadıkça, sosyal ilişkilerin kapitalist "formlarını" konuşmak anlamsız olacaktır. "Biçim" kavramı ile anlatılmak istenen; tarihsel olarak belirlendiği ve tarihsel olarak geliştiği fikirdir. Kapitalist formların bu eleştirisi, Marksist analizin temelini sağlayan geçici formlar olarak ele alınmalıdır (Holloway ve Picdotto, 1978: 27)

Marx ve Engels'in “Alman İdeolojisi”nde insanın toplumsal var oluşunun onun toplumsal bilincini belirlediği tezini ortaya koyarlar ve bu tezi açıklarlar. İnsanın toplumsal yaşamının bütününde üretim biçiminin belirleyici rolünü gösterirler. "Alman İdeolojisi”"ndeki bir diğer ideoloji kavramsallaştırması ise egemen sınıflarla ezilen kesimler ilişkisini yeniden üreten fikirler tanımlamasıdır. "Egemen sınıfin düşünceleri, her çă̆da egemen düşüncelerdir: Yani, toplumun maddi egemen gücü olan sınıf, aynı zamanda egemen fikri güçtür. Maddi üretim araçlarını elinde bulunduran sınıf, bu sayede aynı zamanda zihinsel üretim araçlarının da üzerinde denetim kurar; böylelikle zihinsel üretim araçlarından yoksun olanların düşüncelerini de genel olarak kendine tabi kılar. Egemen düşünceler, egemen maddi ilişkilerin fikri ifadesinden, düşünceler halinde kavranan egemen maddi ilişkilerden, yani o bir sınıfi egemen sınıf yapan ilişkilerden başka bir şey değildir; yani, onların egemenliğinin düşünceleridir’. Marx'a göre ekonomiyi, üretimi ve dağıtımı kontrol edenler, fikirlerin de üretim ve yayılmasını kendi tekellerinde bulundurmaktadırlar. Toplumsal eşitsizlikten faydalanan kesim ideolojiye, eşitsizlikler ve çelişkileri bundan zarar gören kesimlere göstermeme veya farklı sekilerde gösterme amacıyla başvurmaktadır (Marx ve Engels, 2013: 52). Marx ideolojileri ezilen ve eşitsizliklerden olumsuz payı alanlar için bir çeşit bilinçli kurgulanmış senaryolar olarak görmektedir.

Willam Sewell (1985: 58) Marksizm’i olayları hiyerarşik bir nedensellik zinciri içinde ele alması açısından eleştirmiştir. Hiyerarşik yaklaşım ile ilgili sorun, bir faktörün nedensel dinamiklerini başarıyla belirlerken diğer faktörlerin rollerini yalnızca arka plan olarak ele alma eğilimdir. Marksist teori siyaseti kendi oluşumları ve dinamikleri ile ayırıcı bir kurum olarak görmek yerine, yalnızca sınıf iktidarının bir ifadesi olarak görme eğilimindedir. Sewell'in bu tespitleri geleneksel tarihsel materyalizme bir meydan okumadır. Jeopolitik süreci yerel aktörler arasında karar verme süreciyle alakalı ya da alakasız bir arka plana indirgemek yerine, gerçek bir nedensellik etkisi kazandırmıştır. 
İdeoloji ne sınıf ilişkilerinin salt refleksi ne de entelektüellerin toplum hakkında sahip olduğu salt fikirler olarak görülmemelidir. Daha ziyade ideolojiler kurumların yapısını, sosyal iş birliği ve çatışmanın doğasını, nüfusun yatkınlıklarını şekillendirir. Bütün toplumsal ilişkiler aynı zamanda ideolojik ilişkilerdir (Sewell, 1985: 61). Ancak Sewell haklıysa ve ideoloji bu kadar geniş bir kitleye sahipse bile, mantıksal bir bağımsızlık ya da onun belirttiği gibi 3 "kendi özerk dinamiklerini" veren herhangi bir kavramsallaştırmayı sürdürmek zordur. Daha ziyade bu söylemlerin tarihsel gerçekliğinde insan etkileşimin toplumsal ve sınıfsal yönleriyle değişmez biçimde iç içe geçmiş somut süreçler olarak incelenmesi gerekir. Sınıfi ideolojiye dahil etmek yerine somut süreçlerin bütününe duyarlılığ 1 Marx'ın vurgu yaptığı önemli bir husustur (Marx, 2008: 101). Marx soyuttan somuta bir hareketi savunmuştur. Bu soyutlamanın amacı nihai olarak somut tarihsel süreçte gerçek ilişkilerin hareketli bir resmini oluşturur. Marx Sewell’in aksine ideolojik biçimleri doğası gereği içsel olarak bağl1 toplumsal süreç olarak görmüştür.

Günümüzde ise kapitalist modernitenin dış merkezli olduğunu iddia eden bir yaklaşım Skocpol tarafından ortaya atılmışıtır. O Batı'nın sosyolojik modern gelişiminde bir zamanlar içsel bir eğilim olduğunu ancak sonrasında karşı konmaz bir şekilde küreselleştiğini savunmuştur. "Bütün modernleşme süreçleri mutlaka Batı medeniyetlerinden çıkar" çünkü ticari-sanayi ve ulusal devrimlerin ortaya çıktığı yer burasıdır. Bununla birlikte, yakın zamana kadar egemen olan teorik yaklaşımlar çok daha genellemiştir (Skocpol, 1979: 19). Küreselleşme ve onun etkilerini yaşamın her alanında görmek mümkündür. Marx'ın ortaya koyduğu pek çok fikir de bu süreçlerle geçerliliğini yitirmekte ya da evirilip gelişerek yeni çağda bir yankısını bulmaktadır.

\section{SONSÖZ}

Bu makale Marx'ın insan ihtiyaçları, emek ve gerçek özgürlük ile doğal bir ilişkisi olan maddi eşitlik ve esenlik hakkındaki kavramsallaştırmalarını sunar. Makalenin amacı, Avrupa merkezli bir iktisadi determinist olarak yorumlanan Marx'ın, aslında gelişen ve sürekli dinamik sınıf ilişkileri- mücadeleleri ve bunların küresel etkileşimleri hakkındaki anlayışa ve günümüzde kent çalışmalarında önemli bir kavram olarak ön plana çıkan mekan analizlerine temel sağladığını vurgulamaktır. Kullanım değeri ve değişim değerini birbiriyle bağlantılı olarak inceleyen Marx'ın sermaye ve dağılımının sosyal eşitsizlik üstünde yaratığı etkiler üzerine fikirleri de güncel kent çalışmalarında önemli bir kaynak niteliğindedir.

Marx ayrıca, yadsınamaz bir şekilde işgücü merkezli bir kalkınma ve gelişme çalışmaları anlayışı için de temel oluşturur. Marx özellikle sosyal koruma temasını vurgulamamıştır anacak çalışmalarının çok yönlü yapısı genişletilmesi gereken bir refah sosyolojisinin ihtiyacına da dayanmaktadır. Marx'ın insan doğası hakkındaki görüşü o kadar geniş kabul görüyor ki, Marksist öncesi bir insan doğası anlayışına geri dönülmesi pek mümkün görülmüyor. Marx'ın kendi teorisi bilimsel olarak kabul edilmese de insanların yiyecek üretmek için kullandıkları araçlar ile siyasi ve dini inançları gibi görünüşte birbiriyle bağlantılı olmayan yaşam alanları arasındaki ilişkileri araştıran yeni bir sosyal bilimin temellerini oluşturdu. Kuşkusuz ki bu tarih ve sosyal bilimler için verimli bir araştırma alanı olarak gelişmiş ve gelişmeye de devam etmektedir. Marx, ayrıca entelektüel ve manevi yaşamlarımızın ekonomik varlığımızdan tamamen bağımsız olduğu varsayımına da karşı çıkan önemli düşünürlerden birisidir. Sonuç olarak Marksizm sadece bilişsel bir plandan, tamamen entelektüel bir teoriden daha fazlasıdır. Bunun bir eylem rehberi olduğu açıktır. Bunu sadece "iktisadi bir tarih teorisi", özellikle kapitalist toplum ya da daha geniş olarak, sınıf toplumunun ortaya çıkışının bir analizi olarak görenler sadece geçmişe bakıyorlar. Bu vizyonun gücü, eksikliklerine ve başarısızlıklarına rağmen Marksizmin cazibesinin sürekli yenilenmesinin sebebidir. Marx'ın ana fikirlerinin her biri hala pek çok çalışma konusuna ilham olmaktadır. Marx'ın hem teori hem de uygulamadaki etkisi devam etmektedir. Mevcut dünyanın ve mevcut fikir dünyasının o kadar çok yönü var ki, en azından Marx'ın düşüncesinin ana hatlarını anlamadan bunları tam olarak kavrayamayacağız. Bu bile tek başına Marx’ı anlama çabasını haklı çıkarmak için yeterli olacaktır.

${ }^{3}$ Ayrıntılı bilgi için bkz. Sewell, W. H. 1985. "Ideologies and Social Revolutions: Reflections on the French Case" The Journal of Modern History 57 (1) (March 1): 57-85. 


\section{Etik Standart ile Uyumluluk}

Çıkar Çatışması: Herhangi bir çıkar çatışması bulunmamaktadır.

Etik Kurul İzni: Bu çalışma için etik kurul iznine gerek yoktur.

Finansal Destek: Bulunmamaktadır.

\section{KAYNAKÇA}

Barnes, J, B. ve Sheppard, E. 2003. Introduction: The Art of Economic Geography, (Editor(s): Eric Sheppard Trevor J. Barnes), A Companion to Economic Geography, içinde (pages 1-8). Wiley Blackwell

Becker, J. 1977. Marxian Political Economy. Cambridge University Press: Cambridge, UK

Bidet, J. 2008. “A Key to the Critical Companion to Contemporary Marxism”, Critical Companion to Contemporary Marxism kitabı içinde (Edited by Jacques Bidet and Stathis Kouvelakis) Leiden-Boston

Brenner, N., Marcuse, P., Mayer, M. 2014. Kar İçin Değil Halk İçin. (Çev. Ali Yağız Şen). Sel Yayıncılık. İstanbul.

Castells, M., 1977. The Urban Question: A Marxist Approach. MIT Press: Cambridge.

Castree, N. 2013.Valuing The Value of Marx. Capital \& Class. vol. 37(3), p: 482-490.

Dean, H. ve Melrose, M. 1999. Poverty, Riches and Social Citizenship. Macmillan Press: London.

Dorling, D. 2015. Injustice: Why Social Inequality Persists, (2nd Edition) Policy Press: United Kingdom.

Dunford, M. 1988. Capital, the State and Regional Development (Studies in Society and Space). Pion Ltd Publisher.

Dumenil, G. ve Levy, D. 2008. “Old Theories and New Capitalism: The Actuality of a Marxist Economics” Critical Companion to Contemporary Marxism kitabı içinde (Edited by Bidet, J and Kouvelakis, S.) Leiden Boston.

Fainstein, S. 1996. The Changing World Economy and Urban Restructuring, "Readings in Urban Theory" kitabı içinde (Edited by Fainstein, S. and Campbell, S.) Blackwell: Oxford.

Harvey, D. 2002. "Sınıfsal Yapı ve Mekânsal Farklılaşma Kuramı”, (Der. ve Çev. Ayten Alkan ve Bülent Duru) 20. Yüzyıl Kenti kitabı içinde, İmge Yayınevi: Ankara.

Harvey, D. 2003. The New Imperialism. Oxford University Press: New York.

Harvey, D. 2013. Sosyal Adalet ve Şehir. 4. Baskı (Çev. Mehmet Moralı). Metis Yayınevi: İstanbul.

Harvey, D. 2015. Sermayenin Mekânları: Eleştirel Bir Coğrafyaya Doğru. 2. Baskı (Çev. Başak Kıcır ve diğ.) Sel Yayınc1lik: İstanbul.

Holloway, J. ve Picdotto,S. 1978. "Introduction: Towards a Materialist Theory of the State". (Edited by John Holloway and Sol Picciotto. E. Arnold) State and Capital A Marxist Debate Kitabı içinde, Publisher: London.

Lefebvre, H. 2016b. Mekânın Üretimi. (Çev. Işık Ergüden). 4.Baskı. Sel Yayıncılık: İstanbul

Lefebvre, H. 2016a. Şehir Hakkı. (Çev. Işık Ergüde). Sel Yayıncılık: İstanbul.

Lefebvre, H. 2017. Kentsel Devrim. 5. Baskı, (Çev. Selim Sezer) Sel yayıncılık: İstanbul.

Luxemburg, R. 2013. Rosa Luxemburg Kitabı: Seçme yazıları. (Çev. Tunç Tayanç). Dipnot Yayınları.

Marx, K ve Engels, E. 2013. Alman İdeolojisi, (Çev. Tonguç Ok ve Olcay Geridönmez). Evrensel Basım Yayın: İstanbul.

Marcuse, P. 2002. The Divided City in History of States and Cities: The Partitioning of Urban Space. Oxford University Press: Oxford.

Mark, K. 1979. Ekonomi Politiğin Eleştirisine Katkı (4. Baskı) çeviren sevim belli. Sol Yayınları: Ankara. 
Martins, M., R. 1982. The Theory of Social Space in the Work Henri Lefebvre. In Forrest, R. (eds.) Urban Political Economy and Social Theory, Aldershot, Gower Publishing.

Marx, K. 2008. Grundrisse: Ekonomi Politiğin Eleştirisi İçin Ön Çalışma. (Çev. Sevan Nişanyan). Birikim Yayınları: İstanbul.

Marx, K. 2017. Kapital: Ekonomi Politiğin Eleştirisi. Cilt 1., 10. Basım. (Çev. Mehmet Selik ve Nail Satılgan). Yordam Yayıncılık: İstanbul.

Marx, K. 1969. “The Eighteenth Brumaire of Louis Bonaparte.” In Karl Marx and Frederick Engels Selected Works Vol. I, 398 - 487. Lawrence and Wishart: London.

Massey, D. 1984. Spatial Divisions of Labour: Social Structures and The Geography of Production, Macmillan: Basingstoke.

McLellan, D. 2017. Hayalet Karl Marx: Seçme Yazılar. Ayrıntı Yayınevi: İstanbul.

Musterd, S. ve Ostendorf, W., 1998, Urban Segregation and The Welfare State: Inequality and Exclusion in Western Cities. London: Routledge.

Peet, R. ve Hartwick, E. 2015. Theories of Development: Contentions, Alternatives. (Third edt.) Guilford Press: London.

Poulantzas, N. 1969. The Problem of The Capitalist State. New Left Review. vol. 58. p: 67-78

Rousseau, J. J. (1995). İnsanlar Arasındaki Eşitsizliğin Kaynağı ve Temelleri Üzerine Konuşma içinde, (Çev. Rasih Nuri İleri) İstanbul: Say Yay.

Sewell, W. H. 1985. "Ideologies and Social Revolutions: Reflections on the French Case." The Journal of Modern History 57 (1) (March 1): 57-85.

Skocpol, T. 1979. States and Social Revolutions: a Comparative Analysis of France, Russia, and China. Cambridge University Press: Cambridge

Smith, N. 2017. Eşitsiz Gelişim: Doğa, Sermaye ve Mekânın Üretimi. (Çev. Esin Soğancılar) Sel Yayıncılık: İstanbul.

Soja E. 2017. Postmodern Coğrafyalar: Eleştirel Toplumsal Teoride Mekânın Yeniden İleri Sürülmesi. (Çev. Yunus Çetin). Sel Yayıncılık: İstanbul.

Soja, E., 2010. Seeking Spatial Justice. University of Minnesota Press: United States.

Tan, E. 1981. Toplumbilimlerine Giriş Temel Kavramlar. Ankara Üniversitesi Eğitim Bilimleri Yayınları. No:97. Sevinç Matbaası: Ankara.

Wolff, J. 2002. Why read Marx today? Oxford University Press: London 